\title{
Transformasi dan Kontinuitas Dalam Tradisi Penggunaan Bahan Bakar Limbah Jagung Untuk Memasak Skala Rumah Tangga, Studi Kasus Kecamatan Tiga Binanga Tanah Karo
}

\author{
Celerina Dewi Hartati \\ C dewihartati@fs.unsada.ac.id \\ Universitas Darma Persada
}

\author{
Submitted \\ September 30, 2018 \\ Revised \\ June 24, 2019 \\ Accepted \\ June 25, 2019 \\ http://dx.doi.org/10.17509/jpis.v28i1.13299
}

\begin{abstract}
Tiga Binanga Subdistrict consists of 20 villages, and this research was conducted in Simolap village and Tigabinanga village. Corn waste can be functioned as food ingredients and also production materials. Corn cobs or weevils will become waste that is harmful to the environment if there is no good handling. For this reason, corn waste must be utilized so that it is of use. Villagers in Tiga Binanga sub-district in their tradition have long used corn stalks as cooking fuel mixed with firewood and remain in use today. The transformation study so far discusses transformation in relation to continuity, in this paper will be shown the relation of transformation and continuity with tradition and innovation. This paper aims to show the transformation in the use of corn waste as an alternative fuel as well as its continuity as a traditional fuel in the Karo community and its relation to innovation and tradition in the Karo community.
\end{abstract}

Keywords: fuel, corn waste, continuity, tradition, transformation

\begin{abstract}
ABSTRAK
Kecamatan Tiga Binanga terdiri dari 20 desa, dan penelitian ini dilakukan di desa Simolap dan desa Tigabinanga. Jagung dapat berfungsi sebagai bahan makanan dan juga bahan produksi. Tongkol jagung atau bonggol akan menjadi limbah yang berbahaya bagi lingkungan jika tidak ada penanganan secara baik. Untuk itu limbah jagung harus dimanfaatkan sehingga bernilai guna. Masyarakat desa di kecamatan Tiga Binanga dalam tradisinya telah sejak lama menggunakan bonggol jagung sebagai bahan bakar memasak yang dicampur dengan kayu bakar dan tetap digunakan hingga saat ini. Studi transformasi selama ini membahas transformasi dalam kaitannya dengan kontinuitas, dalam tulisan ini akan diperlihatkan kaitan transformasi dan kontinuitas dengan tradisi dan inovasi. Tulisan ini bertujuan memperlihatkan transformasi dalam penggunaan limbah jagung sebagai bahan bakar alternatif sekaligus kontinuitasnya sebagai bahan bakar tradisional di masyarakat Karo dan kaitannnya dengan inovasi dan tradisi dalam masyarakat Karo.
\end{abstract}

Kata Kunci: bahan bakar, limbah jagung, kontinuitas, tradisi, transformasi

\section{PENDAHULUAN}

Kecenderungan pemakaian bahan bakar yang sangat tinggi sedangkan sumber bahan bakar minyak bumi yang dipakai semakin menipis merupakan suatu gejala sosial. Energi memegang peranan yang sangat penting dalam berbagai kegiatan yang menyangkut kehidupan manusia. Jika tidak ada sumber energi maka dapat 
dipastikan seluruh kegiatan manusia akan sulit dilaksanakan. Sumber energi yang dikenal dan dipakai saat ini dapat digolongkan secara garis besar yaitu energi terbarukan dan tidak terbarukan. Sumber energi terbarukan meliputi panas bumi, matahari, angin, air, biomassa dan yang lainnya. Sedangkan sumber energi tidak terbarukan meliputi minyak bumi, gas dan batubara. Jumlah energi tidak terbarukan terus berkurang dan kadang mengalami kelangkaan. Energi terbarukan menggunakan energi alternatif lain sebagai bahan yang dapat digunakan sebagai pengganti minyak bumi.

Salah satu cara yang dapat digunakan untuk mengatasi permasalahan ini adalah dengan memanfaatkan energi terbarukan seperti biomassa yang jumlahnya melimpah. Dalam hal ini sumber energi terbarukan yang cukup memiliki nilai keekonomian yang tinggi adalah biomassa, beberapa contoh jenis biomassa tersebut seperti serbuk kayu, bonggol jagung, sekam padi dan tandan kelapa sawit. Tongkol jagung merupakan limbah tanaman yang setelah diambil bijinya, tongkol jagung tersebut umumnya dibuang begitu saja, sehingga akan meningkatkan jumlah sampah. Untuk itu perlu didayagunakan. Limbah jagung dapat digunakan untuk berbagai hal yaitu sebagai pakan ternak, bahan kuliner, sebagai pengganti bahan plastik, bahan kerajinan, bahan pembakar, dan sebagai pengganti bahan bakar gas. Limbah jagung berupa jerami, tongkol dan klobot jagung merupakan limbah pertanaman jagung yang jumlahnya cukup banyak. Sebanyak 20-30\% dari setiap $100 \mathrm{~kg}$ jagung yang dihasilkan adalah limbah jagung. Limbah ini belum dimanfaatkan secara optimal. Menurut hasil penelitian di Desa Simolap, 1 hektar tanaman jagung akan menghasilkan 9 ton, diperkirakan 1.8-2.7 ton adalah limbah [1]. Limbah jagung belum dikelola secara maksimal, hanya sebagian kecil digunakan sebagai bahan bakar.

Masyarakat Karo menggunakan limbah jagung sebagai bahan pembakar. Para petani jagung memanfaatkan bonggol jagung sebagai kayu bakar. Hal ini lebih ekonomis dan dapat menurunkan kebutuhan energi seperti minyak tanah dan gas. Bentuk ini merupakan yang paling popular di masyarakat. Bonggol-bonggol jagung dikeringkan terlebih dahulu sehingga dengan mudah terbakar dan menghasilkan api yang cukup banyak untuk memasak di tungku. Sebagai pengganti bahan bakar gas, bonggol jagung dapat digunakan sebagai briket untuk memasak. Dengan kasus penggunan bonggol jagung di masyarakat Karo dapat dilihat transformasi dan kontinuitas dalam kaitannnya dengan inovasi dan tradisi yang ada dalam budaya masyarakat.

Kecamatan Tiga Binanga adalah salah satu kecamatan di Kabupaten Karo, Propinsi Sumatera Utara yang merupakan salah satu daerah penghasil jagung terbesar di Kabupaten Karo. Luas wilayah Kecamatan Tiga Binanga adalah 160,38 km2 atau 7,45 persen dari total luas Kabupaten Karo dengan jumlah penduduk sebesar 19.476 jiwa. Seluruh wilayah Kecamatan Tiga Binanga berada pada ketinggian antara 490-700 meter di atas permukaan laut, dengan suhu rata-rata $19^{\circ} \mathrm{C}$ dengan ratarata curah hujan $2500 \mathrm{~mm} /$ tahun, tergolong ke dalam daerah beriklim tropis. Pada tahun 2013, luas lahan jagung Kecamatan Tiga Binanga sekitar 18.652 ha dengan produksi tanaman jagung sebesar 118.006 ton atau ratarata produktivitas sebesar 6,30 ton/ha. 
Varietas jagung yang sekarang dikembangkan adalah hibrida (95\%) [2].

Kecamatan Tiga Binanga berjarak kira-kira $37 \mathrm{~km}$ dari pusat pemerintahan Kabupaten Karo yang memiliki batas-batas wilayah sebagai berikut:

1. Sebelah Utara berbatasan dengan Kecamatan Kutabuluh

2. Sebelah Selatan berbatasan dengan Kecamatan Juhar

3. Sebelah Barat berbatasan dengan Kecamatan Mardingding

4. Sebelah Timur berbatasan dengan Kecamatan Tiga Binanga

Kecamatan Tiga Binanga, Mardinding dan Munthe adalah tiga sentra pertanaman jagung di Kabupaten Tanah Karo. Luas lahan pertanaman jagung di Kabupaten tersebut $44.586 \mathrm{Ha}$ yang terdistribusi di Kecamatan Tiga Binanga seluas 9.962 ha, kecamatan Mardinding 6.345 ha dan Munte 6.807 ha dengan produksi 286.931,5 ton (Dinas Pertanian Tanah Karo, 2007). Jarak dari ibukota Medan $113 \mathrm{~km}$. Luas wilayah Tigabinanga adalah $1820 \mathrm{Ha}$. Penggunaan lahan yang paling banyak diusahakan adalah perladangan dengan luas $1350 \mathrm{Ha}$ (74,17\%), pemukiman $135 \mathrm{Ha}(7,41 \%)$, sawah $55 \mathrm{Ha}$ (3,02\%), tanah yang belum dikelola 261 $\mathrm{Ha}$ (14,34\%). (Dinas Pertanian Tanah Karo, 2007).

Budaya di sini diartikan sebagai bentuk informasi sosial yang disampaikan dalam kelompok sosial atau dengan kata lain budaya sebagai konsep populasi budaya yang dikemukakan [3] dalam Cultural Variation in Time and Space: The Case for a Populational Theory of Culture. Konsep populasi budaya menekankan bahwa budaya adalah sistem evolusi yang berada di tangan mereka sendiri, dan itu membuka jalan untuk menganalisis perubahan budaya sebagai semacam proses evolusi. Durham menunjukkan dengan cara berpikir tentang budaya yang semacam ini memberi alat baru yang berharga untuk berpikir tentang variasi budaya dalam ruang dan waktu. Hal ini sering disebut "teori coevolusi " atau "model coevolusi budaya dengan hipotesanya bahwa budaya adalah sistem perubahan evolusi sejajar dan berinteraksi dengan gen.

Konsep budaya sebagai populasi budaya adalah mengakui bahwa sistem budaya, terdiri dari informasi yang disampaikan melalui ruang dan waktu dalam kelompok sosial. Kebudayaan dari perspektif ini adalah transmisi sosial. Tidak peduli seberapa kecil dan tidak signifikan informasi, pada salah satu ujung spektrum, atau berapa besarnya pada ujung lainnya adalah diajarkan dan dipelajari secara sosial. Suatu budaya, dalam pandangan ini, adalah koleksi lengkap informasi yang ditransmisikan secara sosial dalam suatu masyarakat. Definisi ini sengaja terbuka dimaksudkan untuk merangkul berbagai macam informasi atau fenomena ide, termasuk ide-ide, nilainilai, keyakinan, makna, dan sebagainya.

Konsep budaya atau kebudayaan sebagai konsep populasi budaya sangat berkaitan erat untuk memahami suatu perubahan sosial yang terjadi dalam masyarakat. Singkatnya, budaya tidak dipandang sebagai bentuk tetapi sebagai distribusi. Berpikir tentang budaya populasi adalah bahwa hal tersebut memfasilitasi studi perubahan budaya. [3] berpendapat pemikiran populasi melihat fokus pada perubahan, Begitu banyak hal yang dapat menyebabkan distribusi bergeser-dari peristiwa demografis dasar (migrasi, kelahiran, dan kematian) sampai ke penyakit menular seperti efek varian 
baru-bahwa apa yang menarik adalah untuk bertanya, apa yang menyebabkan perubahan? Budaya dapat dianggap sebagai populasi varian akan representasi, temuan berarti, atau perubahan dari waktu ke waktu karena mereka iteratif disampaikan dalam suatu kelompok, dan dengan demikian berkembang dan berubah.

Konsep kebudayaan yang telah dijelaskan di atas sebagai sebuah kumpulan informasi yang ditransmisikan nampaknya dapat memberikan penjelasan terhadap gejala sosial yang ada dan menjelaskan transformasi atau perubahan sosial yang terjadi [4]. Berbicara mengenai perubahan sosial dan budaya, dapat pula terjadi sebuah proses bahwa "yang tradisional" merupakan invensi (invention of tradition). Sebagai invensi, apa yang disebut "tradisional" sebenarnya bukanlah nilai-nilai lama yang terus bertahan di tengah munculnya nilai-nilai baru. Apa yang "tradisional" ini sebenarnya adalah rekacipta baru dalam sebuah masyarakat. Meskipun dalam invensi tradisi "yang tradisional” itu sebenarnya merupakan ciptaan baru, namun kebaruannya mesti dikaitkan dengan akar-akar dari khazanah kebudayaan lama [5]. Dengan cara inilah tradisi yang baru tersebut seolah-olah memiliki akar yang mendalam di suatu kebudayaan, sehingga memperoleh legitimasi sebagai bagian dari identitas kebudayaan yang bersangkutan. Invensi tradisi merupakan respons atas situasi baru yang mengambil referensi dari situasi lama, atau bahkan membangun sendiri "masa lalunya" melalui repetisi yang seolah-olah wajib dijalankan dari waktu ke waktu.

"... they [invented traditions] are responses to novel situations which take the form of reference to old situations, or which established their own past by quasi-obligatory repetition" [5].

Ketika membicarakan konsepsi transformasi, di dalamnya terkait tradisi dan inovasi. Tanah Karo yang merupakan daerah pertanian, ketersediaan bahan-bahan tanaman, hasil pertanian tidak serta merta membuat petani di di daerah ini beralih mencari energi baru dari bahan-bahan limbah pertanian. Penggunaan energi limbah bonggol jagung merupakan sebuah inovasi dalam tradisi masyarakat Karo, karena keterkaitan dengan tradisi budaya di masa lalu yang mengambil referensi dari situasi lama dalam menghadapi transformasi sosial. Kata transformasi berarti mengendalikan suatu bentuk dari satu bentuk ke bentuk yang lain. Transformasi sosial budaya berarti membicarakan proses perubahan struktur, sistem sosial, dan budaya [6]. Transformasi di suatu pihak dapat mengandung arti proses perubahan atau pembaharuan struktur sosial, dan di pihak lain mengandung makna keberlanjutan. Masyarakat dan kebudayaan terus-menerus mengalami perubahan. Pesatnya kemajuan ilmu pengetahuan merupakan salah satu faktor dominan penyebab cepatnya transformasi sosial. Menurut Emile Durkheim, transformasi sosial merupakan suatu proses perubahan masyarakat dari masyarakat agraris menuju ke masyarakat industri. Dalam rnasyarakat agraris, masyarakatnya bersifat homogen, para anggotanya melakukan kegiatan yang relatif sama sehingga pembagian kerja menjadi sangat sederhana. Selain itu, masyarakat tersebut merniliki nilai-nilai, ide, aspirasi atau tujuan hidup yang juga relatif sama.

Pada saat yang sama, inovasi sosial semakin penting tidak hanya 
dalam kaitannya dengan integrasi sosial dan peluang yang setara, tetapi juga dalam hal kemampuan inovatif dan keberlanjutan masyarakat di masa depan secara keseluruhan. "Meskipun inovasi sosial secara luas diakui sebagai fenomena pembangunan yang penting, secara tradisional dianggap terbatas dalam lingkupnya"[7].

Invensi didefinisikan sebagai kombinasi dari elemen budaya yang sudah ada dan dikenal, material dan / atau non-material, atau modifikasi dari satu untuk membentuk yang baru. Dengan penemuan tersebut terlihat adanya peningkatan secara bertahap. Penemuan, kemudian, adalah bukti di mana kita mendasarkan pengamatan kita tentang evolusi sosial. Dengan demikian, Ogburn yakin bahwa dalam interaksi penemuan, akumulasi, pertukaran, dan adaptasi, ia telah menemukan unsur-unsur dasar perkembangan budaya dan, karenanya, - seperti Darwin untuk evolusi biologis telah mengembangkan suatu model untuk menjelaskan evolusi sosial.

\section{KAJIAN LITERATUR}

Tradisi merupakan warisan dari orang yang terdahulu untuk dilanjutukan ke generasi selanjutnya supaya nilai-nilai yang ada dalam tradisi tersebut tidak terlupakan sepanjang masa. Dalam budaya tradisional, masa lalu sangat dihormati dan simbol-simbol yang ada dihargai karena mereka berisi dan bertanggung jawab jawab atas pengalaman berbagai generasi. Tradisi adalah cara untuk mengintengrasikan tindakan secara refleksif dengan penataan ruang dan waktu dalam komunitas. Ini adalah sarana untuk menangani ruang dan waktu, yang memasukkan segala aktivitas atau pengalaman tertentu di dalam keberlanjutan masa lalu. Tradisi bersifat dinamis, karena ia harus ditemukan ulang oleh setiap generasi baru ketika ia mengambil alih warisan budaya dari pendahulunya. Tradisi merupakan ciriciri suatu bentuk budaya dalam sesuatu yang dinamis dan berubah, dia diteruskan, dijaga dan tidak hilang, ditransmisikan dari waktu ke waktu, diajarkan dari generasi ke generasi dan dipertunjukkan dan dipercayai pada saat ini. Tradisi merupakan sesuatu yang menghubungkan masa lampau dan masa sekarang. Dalam tradisi memperlihatkan perubahan dan keberlanjutan. Menyajikan yang lama dengan penyesuaian yang baru menjadi inti dari sebuah tradisi yang dapat bertahan.

[8] dalam penelitiannya terhadap masyarakat Betawi, menemukan bahwa invensi tradisi yang oleh Shahab disebut sebagai rekacipta, kadang kala menghasilkan efek-efek yang tak terduga atau efek-efek samping. Bahkan, efek demikian kerap kali lebih kuat pengaruh dan jejaknya pada perkembangan suatu masyarakat daripada tujuan yang pada mulanya hendak dicapai. Lebih jauh, [8] menekankan bahwa suatu proses rekacipta hanya dapat berhasil jika memiliki efek ke dalam dan ke luar. Ke dalam, hasil dari suatu rekacipta harus dapat memberikan identitas pada kelompok pemiliknya. Identitas ini merujuk pada eksistensi kelompok yang bersangkutan. Ke luar, hasil rekacipta harus dapat diterima oleh kelompok masyarakat lain di luar lingkaran kelompok pemilik. Dengan cara ini rekacipta tersebut akan memperoleh pengakuan sehingga masyarakat pemiliknya pun terkokohkan identitasnya.

Berdasarkan temuan-temuan dalam penelitiannya, terutama mengenai masyarakat Betawi dan peran 
otoritas dalam membangkitkan "kebetawian", [8] mengategorikan rekacipta tradisi menjadi tiga macam. Pertama, ia sebut sebagai invented tradition, yakni tradisi yang dibentuk yang unsur-unsur pembentuknya bersumber dari tradisi asli. Tradisi semacam ini dibentuk dalam rangka memenuhi kebutuhan yang ada akan identitas suatu etnis atau kelompok masyarakat. Dalam hal ini, tradisi hasil rekacipta memiliki bentuk dan fungsi baru. Kategori kedua dinamakannya recreated tradition, yakni tradisi yang dibentuk dengan memodifikasi bentuk tradisi lama yang disesuaikan dengan tuntutan atau kebutuhan masa kini. Dalam hal ini, tradisi hasil rekacipta memiliki bentuk yang tetap, namun fungsinya baru. Adapun kategori ketiga ia sebut sebagai revived tradition, yakni tradisi yang dihidupkan kembali dengan bentuk dan fungsi yang sama dengan tradisi yang lama. Berbeda dari dua kategori sebelumnya, revived tradition memiliki bentuk dan fungsi yang sama dengan tradisi aslinya.

Kamus Oxford mendefinisikan invensi sebagai : 1 . Proses invensi, 2. Sesuatu yang diketemukan, 3. Tradisi didefinisikan sebagai suatu kebiasaan yang diturunkan. Terdapat dua aliran dalam teori invensi tradisi, yaitu Hobsbawmian dan konstruktifis. Mengenai teori invensi tradisi yang paling umum digunakan adalah Hobsbawm ; seperangkat praktik tradisi yang diciptakan, biasanya diatur oleh aturan baik secara terang-terangan atau diam-diam diterima dari ritual atau simbolik yang berusaha menanmkan nilai-nilai tertentu dan norma-norma perilaku yang secara otomatis berkesinambungan dengan masa lalu [5]. Invensi traisi merupakan suatu praktik dari tradisi tradisi lama untuk melayani tujuan baru. Hobsbawn menambahkan invensi tradisi lebih sering ketika transformasi sosial dalam masyarakat menghancurkan pola sosial yang lama dan invensi tradisi merupakan sesuatu yang berbeda dari kebiasaan (adat) yang didefinisikannya sebagai praktik asli dari masyarakat. Hobsbawm membedakan tradisi antara yang asli dan yang ditemukan berdasarkan bukti sejarah, yang terus ada dipraktikkan melewati waktu demi waktu, sehingga praktik tradisi tersebut dapat diamati secara empiris dan historis. Singkatnya, definisi Hobsbawn mengenai tradisi adalah bahwa tradisi asli memiliki sumber sejarah dari waktu yang telah lama dan kontinuitasnya kelihatan.

\section{METODE PENELITIAN}

Pada penelitian ini, pengumpulan data dilakukan dengan cara wawancara mendalam (indepth interview). Dalam wawancara ini, penulis memperoleh pandangan budaya dan mengidentifikasikan tindakan dan pemahaman orang Karo terhadap praktik pemakaian bonggol jagung yang sangat berlimpah di Kabupaten Tiga Binanga. Selain itu juga pengamatan terlibat (participant observation) dan metode observasi terhadap tindakan yang bersifat komunal yang dilakukan baik di rumah maupun lading-ladang jagung. Informan-informan adalah petani jagung dan juga orang yang memanfaatkan bonggol jagung sebagai bahan bakar untuk memasak. Etnografi ialah suatu pendekatan empiris sekaligus teoretis yang merupakan turunan dari antropologi, yang bertujuan utama untuk menghasilkan deskripsi yang mendetil dan holistik serta analisis budaya yang didasarkan pada kerja lapangan yang intensif. Adapun semiotik adalah ilmu yang mengkaji tanda atau makna dalam kehidupan manusia. Selain itu kedua 
metode penelitian di atas, juga diterapkan metode kajian pustaka, dengan menggunakan beberapa literatur seni dan budaya sebagai sumber acuan.

\section{HASIL DAN PEMBAHASAN}

Penelitian lapangan ini dilakukan di bulan Mei tahun 2018 di dua buah desa di Kecamatan Tiga Binanga, yaitu Desa Tiga Binanga dan desa Simolap. Penelitian ini terkendala dengan adanya erupsi gunung Sinabung. Panen jagung yang diharapkan ada pada bulan Februari, pada saat kami melakukan penelitian, belum panen karena terkena dampak erupsi letusan gunung Sinabung. Masyarakat di kecamatan Tiga Binanga merupakan masyarakat petani, khususnya petani jagung. Terjadinya bencana meletusnya gunung Sinabung berdampak yang sangat besar terhadap kondisi masyarakat di Tanah Karo khususnya kecamatan Tiga Binanga. Jagung yang merupakan hasil terbesar dari masyarakat Karo sering terjadi gagal panen. Dengan berkurangnya panen jagung yang akan menjadi bahan sumber energi terbarukan juga menjadi terganggu. Selain kedua desa tersebut, penelitian juga dilakukan di desa Rumah Berastagi, Kecamatan Berastagi.

Kecamatan Tiga Binanga merupakan salah satu kecamatan yang terkena dampak erupsi gunung Sinabung, sementara Kecamatan Berastagi lebih aman dari bencana erupsi ini namun juga terkena dampak debu vulkaniknya. Di Desa Rumah Berastagi, kami mengamati bahwa di tempat ini sudah tidak ada lagi kilang papan, tidak ada lagi limbah serbuk kayu. Menurut informasi sebelumnya dan pengamatan sepintas, di Desa Rumah Berastagi terdapat banyak limbah serbuk yang digunakan untuk memasak namun ketika ditanya mengenai penggunaan briket, orangorang di tempat ini mengatakan tidak tahu dan tidak mengenal. Ketika kami sampai di Desa Rumah Berastagi pada awal bulan Mei 2018, kami tidak dapat menemukan orang yang menggunakan limbah serbuk kayu untuk memasak.

Penduduk desa Rumah Berastagi semua menggunakan bahan bakar elpiji untuk memasak, penggunaan kayu bakar pun yang biasanya masih digunakan untuk memasak di dearah Tanah Karo, tidak lagi dijumpai di desa ini. Orang menggunakan bahan bakar elpiji untuk memasak baik makanan sehari-hari maupun memasak makanan tradisional. Secara budaya dan juga dalam sejarahnya orang Karo menggunakan bahan bakar kayu untuk memasak dan bahkan ketika sudah digunakannya minyak tanah dan elpiji untuk memasak, mereka tetap menggunakan kayu untuk memasak karena diyakini bagi banyak orang jika memasak menggunakan kayu, masakan akan terasa lebih lezat. Masakan tradisional khas Karo, seperti tasak telu, cipera dimasak dengan menggunakan kayu bakar.. Alasan tidak lagi digunakannnya kayu bakar untuk memasak karena ketidakpraktisan dan membuat alat masak, serta atap ataupun sekitar menjadi kotor. Orang lebih memilih menggunakan elpiji karena praktis, harganya yang lebih terjangkau dan menjaga alat masak dan sekitar tetap bersih.

$$
\text { Desa Rumah Berastagi }
$$

nampaknya belum mengenal energi alternatif. Ketika sumber energi terbarukan diperkenalkan dan diprogramkan menjadi bahan bakar alternatif, upaya mendorong masyarakat menggunakan energi terbarukan belum dikenal di daerah ini. Tidak hanya Desa Rumah Berastagi, ke 
delapan desa lainnya di Kecamatan Berastagi juga belum mengenal dan belum menggunakan sumber energi terbarukan. Kami telah menelusuri daerah-daerah di Kecamatan Berastagi dan juga berdasarkan informasi dari informan, bahwa di Kecamatan Berastagi tidak ada penggunaan energi terbarukan. Istilah energi terbarukan pun belum dikenal oleh masyarakat di Kecamatan Berastagi.

Pemilihan penggunaan energi terbarukan dengan menggunakan limbah tongkol jagung dilakukan di Kecamatan Tiga Binanga yang berjarak $31,1 \mathrm{~km}$ dengan Berastagi. Terdapat dua desa yang kami ketahui menggunakan energi alternatif yaitu Desa Tiga Binanga dan Desa Simolap. Erupsi gunung Sinabung sangat berpengaruh pada hasil panen jagung. Di tahun 2018, bulan Mei belum ada panen jagung, ladang jagung belum dipenuhi jagung yang siap panen. Sepanjang jalan di Kecamatan Tiga Binanga dipenuhi dengan ladang jagung dan pohon kemiri. Menurut penuturan seorang ibu, tongkol jagung sudah sejak lama digunakan masyarakat Karo selain untuk memasak, juga untuk menyetrika baju. Tongkol jagung menjadi bahan bakar untuk memenuhi kebutuhan sehari-hari. Tongkol jagung dibakar dan ini menjadi pengganti arang dan digunakan untuk menyetrika. Orang harus dengat cepat menyetrika menggunakan panas dari tongkol jagung ini, karena selain dapat merusak pakaian juga dapat menjadi tidak panas lagi. Penggunaan tongkol jagung untuk menyetrika masih ada sampai tahun 1980 an. Ibu tersebut menceritakan penggunaan tongkol jagung sebagai alat setrika berdarkan pengalamannya.

Di desa pertama tempat kami melakukan penelitian lapangan adalah Desa Simolap, desa ini merupakan desa percontohan di kabupaten Tanah Karo pada tahun 2017. Dipilihnya Desa Simolap menjadi desa percontohan di kabupaten Tanah Karo berdasarkan kriteria sebagai berikut cuci tangan sebelum makan, tidak merokok di dalam rumah,memiliki jamban yang sehat, makan buah dan sayur, persalinan ditolong tenaga kesehatan, memberikan ASI eksklusif, menimbang balita setiap bulan, air bersih, memberantas jentik nyamuk Limbah jagung berupa tongkol jagung, serasah jagung ditemukan sangat berlimpah di Desa Simolap. Limbah jagung dapat ditemukan di ladang, tempat penggilingan jagung, halaman rumahrumah penduduk dan ladang jagung. Sebagian besar limbah tersebut dibiarkan tertumpuk tanpa dilakukan pengolahan, sebagian kecil limbah tersebut diangkut oleh truk-truk ke kota Medan yang akan digunakan sebagai bahan baku makanan ternak dan pembuatan tempat telur Berdasarkan penelitian sebelumnya yang dilakukan oleh [9] dalam pembuatan briket limbah jagung menyatakan petani belum memiliki pengetahuan dan keterampilan yang cukup dalam mengolah limbah jagung menjadi briket bahkan pengetahuan atau informasi bahwa limbah jagung dapat digunakan sebagai bahan bakar alternatif minyak tanah dan gas pun mereka belum mengetahui. Penelitian yang mereka lakukan di tahun 2014, saat panen raya jagung di Kecamatan Tiga Binaga jatuh pada bulan Juli 2014.

Pada bulan Mei 2018, belum terjadi panen jagung. Ladang jagung dipenuhi jagung yang belum siap panen. Keadaan seperti itu tentu saja membuat belum adanya limbah jagung yang dapat digunakan sebagai bahan bakar alternatif. Di Kantor desa Simolap di kecamatan Tiga Binanga, mesin pembuat briket terletak begitu saja, 
para penduduk sibuk ke ladang. Di sekitar rumah penduduk, banyak terlihat ibu sedang memecah kulit kemiri. Dengan menggunakan sebuah pemukul, ibu-ibu dengan cekatan memecah kulit kemiri. Kulit kemiri dimasukkan dalam karung dan siap untuk dijual Satu karung kulit kemiri dihargai Rp.30.000,-. Tidak tampak penggunaan pemakaian briket limbah jagung., hal ini dikarenakan belum masa panen jagung sehingga tidak adanya limbah jagung. Orang lebih mengenal limbah jagung sebagai bahan bakar tidak dalam bentuk briket. Penggunaan limbah jagung dikenal sebagai bahan bakar tetap dalam cara tradisional. Penggunaan limbah jagung di masa modern digunakan dengan cara yang sama dengan tradisional. Maksud dari penggunaan limbah jagung secara tradisional di sini adalah, orang-orang menggunakan limbah jagung yaitu tongkol jagung sebagai bahan bakar memasak dicampur dengan penggunaan kayu bakar dan kulit kemiri namun ada juga yang hanya menggunakan tongkol jagung. Seorang ibu mengatakan, untuk apa menggunakan tongkol jagung jika elpiji sudah lebih murah dan sangat praktis. Menurutnya, dengan harga subsidi elpiji maka pengunaan tongkol jagung sebagai bahan bakar tidak menjadi pilihan. Mesin pembuatan briket limbah jagung selama tidak ada panen jagung menjadi tidak terpakai dan pemakaiannya hanya karena mendapat bimbingan dan arahan dari para akademisi. Orang lebih menggunakan elpiji karena praktis.

Di Desa Tiga Binanga, seorang Ibu yang sudah tiga puluh tahun lebih berjualan di pasar Tiga Binanga mengatakan ia menggunakan limbah jagung untuk memasak. Ibu ini berjulan masakan; ikan arsik, lemang. Di rumahnya terdapat berkarung-karung tongkol jagung, dan kulit kemiri. Ia mengatakan memasak ikan arsik dengan campuran kayu, tongkol jagung, dan kulit kemiri membuat masakannnya yaitu ikan arsik lebih enak. la tidak menggunakan elpiji karena ia merasa ikan arsik yang dimasak dengan campuran bahan bakar yang disebutkan tadi sudah menjadi kebiasaannya dan ia tidak ingin menggantinya. Serupa dengan keadaan di desa Simolap yang penduduknya juga lebih memilih elpiji untuk memasak dan memenuhi kebutuhan sehari-hari yang dirasakan lebih murah dan praktis.

Penggunaan limbah jagung di Kecamatan Tiga Binanga belum maksimal dan penduduk setempat masih lebih menyukai bahan bakar elpiji.Pengenalan sumber energi alternative belum dirasakan oleh banyak orang, kepraktisan lebih menjadi pilihan orang-orang.

\section{SIMPULAN}

Kesimpulan yang dapat ditarik dari penelitian ini adalah, meskipun manfaat limbah jagung sangat banyak namun belum dapat dimaksimalkan oleh penduduk desa Tiga Binanga. Limbah jagung dapat berfungsi sebagai pakan ternak. Tongkol jagung dibuat tepung kering sebagai bahan pakan ternak. Akan tetapi manfaat yang semacam ini belum dimanfaatkan oleh petani tiga binanga. Orang di Tiga Binanga masih menggunakan tongkol jagung sebagai kayu bakar. Meskipun hal ini lebih ekonomis dan dapat menurunkan kebutuhan energy seperti minyak tanah dan gas namun juga bagi orang Karo dirasakan tidak praktis. Masih adanya yang menggunakan limbah jagung sebagai bahan bakar karena memiliki tujuan tertentu seperti menjual masakan tradisional. Tongkol jagung 
dikeringkan terlebih dahulu sehingga dengan mudah akan terbakar dan menghasilkan api yang cukup banyak untuk memasak di tungku. Kadang ditambah dengan kayu, kulit kemiri dan bekas sandal jepit karet untuk mempercepat dan memperbesar api.

Pemakaian limbah jagung dapat dikatakan sebagai bentuk proses perubahan sosial budaya karena dalam sejarahnya dan masa lampau orang memasak menggunakan kayu dan seiring dengan kemajuan dan perkembangan zaman, orang mulai meninggalkan kayu dan menggantinya dengan minyak tanah atau gas. Namun sebagai suatu proses budaya, di satu sisi dia berubah, di satu sisi dia dapat bertahan. Contohnya pada seorang ibu yang tetap menggunakan tongkol jagung untuk memasak masakan tradisional untuk dijual karena tidak mau menggantinya. Inilah yang merupakan budaya sebagai bentuk kumpulan informasi yang terus dia pertahankan. Sebagai sebuah invensi, orang menemukan limbah tongkol jagung sebagai bahan bakar alternative dengan dipadu dengan bahan lain misalnya kayu bakar, kulit kemiri dan karet dalam hal ini bekas sandal. la mengambil bentuk lama dan ditemukan dengan hal y Rakhmat ang baru.

Masyarakat dalam memahami kebudayaan dalam hal ini orang Karo yang dikenal sangat kuat mempertahankan tradisi budayanya, dalam penggunaan energy lebih memilih suatu alasan kepraktisan dan ekonomis. Orang Karo di Tiga Binanga lebih memilih gas sebagai bahan bakar karena harganya murah. Pemakaian tongkol jagung segai limbah yang dapat menggantikan energy belum dapat diterapkan secara maksimal.

\section{DAFTAR PUSTAKA}

[1] Karo Dinas Pertanian Tanah, “Limbah Jagung," 2007.

[2] Badan Pusat Statistik Kabupaten Karo, 2013.

[3] W. Durham, "Cultural Variation in Time and Space: The Case for a Populational Theory of Culture," Anthropol. Beyond Cult., pp. 193206, 2002.

[4] J. Murchison, "Ethnography essentials: Designing, conducting, and presenting your research," vol. 25, 2010.

[5] E. Hobsbawm and T. Ranger, The Invention of tradition. Cambridge University Press, 1992.

[6] J. Rakhmat, "Rekayasa sosial: reformasi atau revolusi?," Remaja Rosdakarya, 1999.

[7] Millard, "Toward a coherent methodological framework for examining social innovation in the public sector.," nformation Syst. Manag., vol. 31, no. 3, pp. 250-258, 2014.

[8] Y. Z. Shahab, Identitas dan otoritas: rekonstruksi tradisi Betawi, Cet. 1. Depok: Laboratorium Antropologi, FISIP UI, 2004.

[9] R. Aziz, S. Suswati, and A. Indrawati, "BRIKET LIMBAH JAGUNG SEBAGAI SUMBER ENERGI ALTERNATIF RAMAH LINGKUNGAN DI DESA SIMOLAP KECAMATAN TIGABINANGA KABUPATEN TANAH KARO," J. Abdimas, vol. 19, no. 2, 2015. 